\title{
China Perspective in Reforming of the World Trade Organization
}

\author{
Asif khan ${ }^{1}$, Ahmad Arafa Abd Elrhim ${ }^{1}$, Nishan-E-Hyder Soomro ${ }^{1}$ \& Muhammad Abid Hussain Shah Jillani ${ }^{1}$ \\ ${ }^{1}$ School of Law, Zhengzhou University, Zhengzhou, China \\ Correspondence: Muhammad Abid Hussain Shah Jillani, Doctoral candidate at School of Law, Zhengzhou \\ University, Henan, China. E-mail: dr_abidshah@gs.zzu.edu.cn
}

Received: November 16, 2020

doi:10.5539/jpl.v14n2p104
Accepted: December 20, $2020 \quad$ Online Published: January 30, 2021

URL: https://doi.org/10.5539/jpl.v14n2p104

\begin{abstract}
In recent years, the World Trade Organization (WTO), the multilateral trading system, has faced many difficulties and challenges due to the great vows of anti-globalisation and trade protectionism. The appellate body, as a significant portion of the Dispute Settlement Mechanism (DSU) of the WTO, has been suffering from an unprecedented crisis of suspension because the United States continues to prevent the appointment of vacant members. Now to save the World Trade Organization from an unprecedented crisis of survival reform has become a consensus. However, each member has a different opinion concerning the basic principle and specific contents of WTO reforms. In general, it is proposed to increase the flexibility of the negotiation mechanism and break the deadlock in multilateral negotiations caused by "consensus" and advocate the system in terms of substantive rules. It is proposed to establish new trade regulations, strengthen trade fairness, and eliminate investment Obstacles; in terms of disciplinary constraints, it advocates better use of the WTO's review and supervision functions and strengthens the constraints on members' compliance with transparency and notification obligations. In dispute settlement, it proposes to amend the relevant agreements as soon as possible To break the deadlock in the selection of judges of the Appellate Body and ensure the regular operation of the World Trade Organization. China clarifies its primary position and fundamental concerns, based on the existing paper, and introducing specific reform programs to participate more effectively in the WTO reform process. Qualitative research methodology has been applied to the following article.
\end{abstract}

Keywords: China, consensus, Dispute Settlement Mechanism (DSU), WTO, WTO reforming

\section{Introduction}

As one of the three Bretton Woods institutions that reshaped the global economic order after World War II, World Trade Organization (WTO) is the most complete, perhaps the most prestigious International Economic Organization in the world today (Bretton Woods, 2019). Its vast coverage agreement system, clear free trade principles, and mature dispute settlement mechanism provide a valuable supply of rules and institutional compliance for international economic and trade activities. It is a benchmark for global economic governance. Some scholars even call it "model international law" (Shaffer, G., \& Gao, H, 2018). However, it has not been more than 20 years since its formal establishment, and the WTO has a bleak, torn uncertain future. The Doha round Negotiations come to an end, and the WTO is stuck in a development impasse. The sudden emergence of broad regional trade agreements makes the multilateral system bear "elevated" pressure. Since 2017, the US has openly resisted selecting the Appellate Body judges, which has made the organisation face a crisis of survival.

From the current attitudes of the primary members, there is consensus on the WTO's survival, which means that they all recognise the importance of the WTO-based multilateral trading system and hope to continue. Even the US is determined to suspend the Appellate body's function; however, it also did not negate the value of the WTO's existence. The strict stance on the mechanism has not yet been used as a bargaining chip, forcing the trading partners to make a more substantive rule.

On the issue of development, members have different attitudes and understandings. On the one hand, all parties agree to reform the WTO to break the deadlock and regain vitality. On the other hand, regarding the principles, content, and priorities of the reformed order, each has its preference and emphasis. Presently papers have been published or submitted by members the primary texts include: "Concept of Modernization of the WTO" (after this referred to as WTO Modernization Concept Paper) issued by the European Union on September 18, 2018, EU Scheme) (WTO, 2018). Ottawa Department of Trade on WTO Reforms hosted by Canada on October 25, 2018, 
Joint Communiqué of WTO Reforms (after this referred to as the Ottawa Communique); (Canada, 2018) and EU, China, Canada, India on November 26, 2018, jointly submitted Two proposals to break the deadlock in the selection of judges in the current appellate body (WTO-General Council, 2018). Besides, on November 23, 2018, the Ministry of Commerce of the People's Republic of China issued "China's Position Paper on WTO Reform" (From now on referred to as the position paper), clarifying China's three principles and five points on WTO reform (Embassy of the PR China in the Republic of Rwanda, 2018). This article focuses on the above texts, substantive rules, disciplinary constraints, and dispute settlement from the negotiation mechanism.

\section{Negotiation Mechanisms}

Ideally, the WTO has both legislation (rule-making), law enforcement (enforcement rules), and judicial (applicable rules, dispute resolution) function that can effectively ensure the provision of rules and institutions in the field of international trade. However, the fact is that since its establishment, the legislative function of the WTO has almost stagnated (WTO FTA, 2017). The Doha Round negotiation launched in 2001 lasted a long time; as a result, the WTO was unable to adapt to the development and changes of the actual situation, supplement and update the corresponding rules, which not only made it difficult to bridge the differences between the members however also led to the dilemma between the Panel and the Appellate Body in the process of dispute resolution. on the one hand, due to the failure to update the rules at the legislative level, to change the face of reality, in order to ensure the vitality of the rules, they can only explore rules on a case by case basis and even break some of the local development; on the other hand, these The accumulation of developments and breakthroughs over a long period will inevitably lead to inconsistencies and incoherence within the rule system, and it will lead some members to accuse them of infringing "legislative power."

There are many reasons for the loss of the legislative or negotiation functions of the WTO; however, from a procedural perspective, the "Consensus" decision-making mechanism is undoubtedly an objective obstacle. Historically, early in the GATT era's decision-making principles, there were two "line" disputes: First, the traditional one-country, one-vote system, which conformed to the principle of sovereign and equal international relations, however, was met by the United States and Japan. The opposition of major trading nations such as Europe and other trading nations objected that it did not accurately reflect the reality of the world economy, nor can they adapt the rights and responsibilities of members; the second is the weighted voting system that the United States is trying to introduce, i.e., following the "capital majority" followed by international financial organisations, the principle of "decision" converts the economic strength of the members and other factors into voting rights in a certain way. However, underdeveloped and least developed countries have resisted this. As a compromise, GATT started a consensus decision-making mechanism in 1960. The advantage of this mechanism lies in bridging the differences to the greatest extent, reaching consensus, and ensuring the comprehensive coverage of the rules. The disadvantage is that each member theoretically has a "veto power," which can prevent the agreement's final agreement. When there are significant differences in positions, the formulation or modification of the rules cannot be achieved.

The WTO inherited a consensus decision-making mechanism. Article 9 of the 1994 Marrakesh Agreement Establishing the World Trade Organization stipulates that the WTO shall continue to adopt the consensus-based decision-making approach followed by GATT1947, which means that "when a decision is made, no member present at the meeting has formally opposed it the proposed decision, the relevant body shall be deemed to have decided on the matter referred to it by consensus. " Although the article also stipulates that if a decision cannot be reached by consensus, a country shall vote with one vote and, depending on the situation, adopt a striking or straightforward majority such a $2 / 3$ or $3 / 4$ according to the situation, however, this rule remains on paper only, not implemented in actual practice. This leads to the low efficiency of WTO negotiations, which are subject to deadlock, as evidenced by the Doha Round negotiations.

The European Union plan proposes "plurilateral negotiations" involving some members to break the deadlock of "multilateral negotiations" subject to the principle of consensus. In particular, on the one hand, continuing to support comprehensive multilateral negotiations where possible; On the other hand, it promotes plurilateral negotiations in areas where multilateral agreement cannot be reached and is open to members who are willing to join. The results of the negotiations are based on the MFN principle. "The EU plan" does not specify the specific areas, however, according to the "trade revival and inclusive growth," report jointly released by the WTO and the International Monetary Fund and the World Bank on September 30, 2018, the areas involved mainly include ecommerce, investment facilitation, services and domestic regulation of small and medium micro-enterprises (WTO International Monetary Fund, 2019). The "Open Plurilateral Negotiations" The similarities between the existing plurilateral agreements, such as the Procurement Agreement, lie in the fact that they are between some WTO members. However, the difference is "openness," that is, other members can join at any time. All members' 
treatment promised by the relevant members can be enjoyed based on the most favoured nation principle (WTO International Monetary Fund, 2019). This position was echoed in the "Ottawa Gazette," "Tackling contemporary economic and trade issues and completing outstanding work is crucial to ensuring the value of the WTO, this requires flexible and open negotiations method to achieve multilateral results." It is worth mentioning that the 13 members participating in the Ottawa meeting of trade ministers include Australia, Brazil, Canada, Chile, the European Union, Japan, Kenya, South Korea, Mexico, New Zealand, Norway, Singapore, and Switzerland basic cover the major economies in the world except China and the United States. The degree of representativeness reflects the urgent desire of WTO members to reform the decision-making mechanism and promote the creation of rules (Canada, 2018).

The relative expression in the position paper is two-fold. The first is "WTO reform should follow consensus Coherent decision-making mechanisms. The selection of reform issues and the outcome of Reform should be decided by consensus." Second, "Reform should maintain the main channel of the multilateral trading system in the process of global trade liberalisation and facilitation. We should not confuse and negate the authority of the multilateral trading system with so-called new concepts and new expressions" (United Nations Economic and Social Commission for Asia and the Pacific, 2019). At first glance, this position may seem opposed to the above proposal; however, it is not always the case. First, the position paper Emphasises that the Reform should follow the consensus decision-making mechanism, that is, what to change and how to change, should be consistent decisions by consensus, however not exclude the inclusion of "consensus" itself in the reform agenda. Secondly, the plurilateral negotiations results are only as effective as the limited members participating in the negotiations. If applied to all members, the multilateral rules still need to follow the principle of consensus (CNUCED, 2000). In this regard, there is no inevitable conflict between the "progressive" of plurilateral negotiations and the "uniform consensus" of multilateral negotiations. However, it is still necessary to maintain an appropriate balance between multilateral and plurilateral agreements, as well as overall and partial, so as not to plunder the plurilateral agreements and "over to head" multilateral agreements, resulting in the de facto fragmentation of the international trading system (Nakatomi, M, 2013). This is precisely the Position Paper's significance is emphasising maintaining the "principal channel status" of the multilateral trading system.

\section{Substantive Rules Issues}

In terms of substantive rules, the current reform demands of the members concerned to focus on two main aspects mainly, one of which is strengthening the existing rules and formulate new rules to restrict state-owned enterprises and promote fair competition, the other is to formulate new rules to solve service and investment barriers, including eliminating digital trade barriers (Bartels, L, 2019).

WTO was initially based on free trade, however in recent years, especially in the face of China's emergence in the global trade system, the United States, Europe, and other Western countries have turned their attention to the fairness" of international trade. Since Trump's administration, the United States has always emphasised freedom, fairness and reciprocity'in trade policy. When Trump took office in 2017, he made a high-profile withdrawal from the Trans-Pacific Partnership (TPP) because it was not fair and equitable to the United States. Although they are not inferior to the United States on trade issues and may not fully agree with the "equivalent" argument, in calling for greater trade fairness, thereby limiting and restricting the competitiveness of Chinese enterprises, the developed western economies such as the European Union, Japan, and the United States is basically on the same front. On May 31, 2018, the US, European, and Japanese Trade Ministers issued a joint statement (from now on referred to as the "May Joint Statement"), emphasising that "market-oriented conditions are indispensable to a fair and mutually beneficial global trading system" and stated that Committed to responding to "non-market-oriented policies and practices that cause severe overcapacity and cause unfair competition for our workers and businesses" (EU and WTO, 2020 \& Deng, Y, 2020). On September 25, 2018, the US-Europe-Japan Tripartite Joint Statement (from now on referred to as the "September Joint Statement") reiterated the above concerns and stated that it was working on the formulation of "new rules on industrial subsidies and state-owned enterprises to provide Creating a more level playing field with companies "and responding to" the challenges posed by third parties developing state-owned enterprises into national champions and placing them in global markets" (EU and WTO, 2020).

The EU Plan has a more specific explanation of the issue of enhancing the fairness of WTO rules. Its core concern is the issue of state-owned enterprises and related subsidies. Specifically, the first is to capture better state-owned enterprises, including more clearly defining the constituent elements of a "public institution" to determine whether a state-owned enterprise is performing government functions or promoting government policies, and clarifying how to judge specific Whether members are implementing "meaningful control" on related enterprises; the second is to more effectively restrict the subsidies that have the highest degree of trade distortion, such as domestic subsidies that cause severe overcapacity, including listing as prohibitive subsidies. The current prohibitive 
subsidies under the Agreement on Subsidies and Countervailing Measures (from now on referred to as the "Subsidy Agreement" include export subsidies and import substitution subsidies only), or severe presumptive prejudice required by actionable subsidies. In short, it is necessary to expand the negotiation agenda, formulate new trade regulations, re-balance the system, and create a level playing field (Büge, 2013).

The discussion in the EU Plan on state-owned enterprises and their subsidies is essentially a continuation of the issue of "competitive neutrality." The concept of "competitive neutrality" originated from Australian domestic competition law; however, it was first proposed by the United States in a transnational context and stipulated in the TPP state-owned enterprise chapter. Although the TPP has perished due to the US withdrawal, the Comprehensive Progressive Trans-Pacific Partnership Agreement (CPTPP), the successor, retains the state-owned enterprise chapter and its competitive rules neutrality. The US-Mexico-Canada Agreement (USMCA), released in October 2018, also follows the TPP model, setting up a state-owned enterprise chapter and competition neutral rules. The reason why the United States has set up state-owned enterprise chapters in TPP and other broad regional trade agreements and emphasises the principle of competitive neutrality is principal to compete for the dominance of global economic and trade rules and to consolidate and strengthen its traditions. Competitive advantage restricts and weakens the competitiveness and influence of China's economic model. The rules on competition neutrality under the TPP deviate from the original purpose of 'state-owned enterprises returning to the nature of the company' under the Australian model and the 'ownership neutral' status maintained by the WTO, which constitutes a significant amount of restrictions on competition and discrimination against state-owned enterprises (Lee, 2017 \& China Economic Times, 2016).

China does not need to exclude competitive neutrality. The fair competition between state-owned and private enterprises is originally in line with the basic economic system for the joint development of China's various ownership economies. The meaning of the title "unswervingly encourage, support and guide the development of the non-public ownership economy" (Liangyu, 2018). In addition to focusing on trade fairs, the EU Plan advocates new rules to remove barriers to services and investment, including the issue of mandatory technology transfer. Specifically, the plan considers the need to address barriers to market access, discriminatory treatment of foreign investors, and post-border distortions, including when it linked to mandatory technology transfer and other trade distortion policies, as well as digital trade and barrier issues. These demands for Reform reflect the reality of insufficient supply of WTO system, lagging in the formulation of rules, and the desire of developed members to expand the negotiation agenda and cover more investment issues, which are reasonable to some extent. Simultaneously, the emphasis on compulsory technology transfer and related digital trade barriers is very obvious to China, especially considering the background of Sino US economic and trade frictions. In this regard, we need to consider comprehensively and deal with it carefully.

\section{Disciplinary Issues}

As far as disciplinary constraints are concerned, the currently more real concern is that the WTO's monitoring and supervision functions are insufficiently implemented, and the tracking and restraint of members' compliance with transparency and notification obligations are weak. The area of subsidies is a prominent example. The "Joint Statement in May" states: "Many WTO members do not report at all or do not report most of the subsidies granted or maintained in their territory, making it impossible for other WTO members to assess the effects of trade and understand the reported subsidy items." The EU Plan stated more directly:" The lack of comprehensive information on subsidies provided to members is one of the most significant shortcomings in the operation of the current system. Although the "subsidy agreement" has required members to report their subsidies, compliance Poor and worsening situation in recent years, as of March 2018, half of the members (90) have not made any notifications. Without transparency in the subsidies, members cannot review each other's actions and face challenges in seeking enforcement of the rules. A significant obstacle that significantly weakens the value of physical discipline. "The Ottawa Communique maintains a similar attitude, however, states from a broader perspective" (WTO, 2018). We should strengthen the supervision of member trade policies and policy transparency, which ensures WTO members Keeping abreast of the policy actions taken by their trading partners Members comply with the duty to inform the overall recording worried. "In this context, the three parties the United States and Europe" agreed to submit a joint program on transparency and communication issues on September Joint Statement "for consideration by the Council for Trade in Goods.

The "US, Europe, and Japan Plan" is a draft General Council resolution called "Procedures for Enhancing Transparency and Notification Requirements under the WTO Agreement," which mainly includes the following.

First, reaffirm the "Agricultural Agreement," "Agreement on the Implementation of Article 6 of the GATT 1994 (Anti-dumping)", "Subsidy Agreement," "Agreement on Safeguards," "Understanding on the Interpretation of 
Article 17 of the GATT 1994 (State Trade)", and "On the Implementation of Article 7 of the GATT 1994" Articles of Agreement (Customs Valuation), Agreement on Import Licensing Procedures, Agreement on Rules of Origin, Agreement on Pre-shipment Inspection, Decision on Notification Procedures for Quantitative Limit Measures, Agreement on Trade-Related Investment Measures, Implementation of Sanitation and Plant Existing notification obligations under agreements such as the Agreement on Health Measures and the Agreement on Technical Barriers to Trade (from now on referred to as the "Listed Agreement").

Second, the establishment of a "Notification Obligations and Procedures Working Group" (from now on referred to as the "Working Group"), which is responsible for conducting annual assessments of the compliance of members with the notification obligations under the listed agreements and submits reports to the corresponding supervisory agencies and how to improve Third, since 2019, independent standardised reviews have been added to all trade reviews of the compliance of members with notification obligations under the listed agreements.

Fourth, and most substantive, is to authorise the WTO to take several punitive measures against members who do not comply with their notification obligations and do not intend to change. If a member has not adequately notified within one year after the prescribed notification deadline, the following measures can be taken against him from the second year:

- his representative shall not appoint as chairman of the WTO body.

- The member Questions asked to other members during the trade review period need not be answered by the latter.

- A certain percentage of additional membership fees are levied on the member (World trade online, 2019).

- The Secretariat reports its notification to the Council for Trade in Goods each year; a special report was given at the meeting.

If the situation has not changed, from the third year, the following measures can be taken:

- the member is referred to as an "inactive member."

- at the formal meeting of the WTO, the member is only available to all other members. They can only speak after they have finished speaking.

- When the member speaks at the General Council, he will be designate as an "inactive member"(World trade online, 2019).

\section{Dispute Settlement System of WTO}

The mature and standardised dispute settlement mechanism, which is the label of WTO proud, is known as the "pearl on the crown" of WTO. However, it is precisely the differences between the members and more precisely, between the United States and other members - on the dispute settlement mechanism, especially the appellate body's operation. The consequent US blatantly prevents the selection of new judges, which causes the appellate body and even the whole dispute settlement mechanism to face the risk of "suspension," which makes the WTO fall into an unprecedented crisis of survival (Article 17.1 DSU, 2018).

According to the president's trade policy agenda issued by USTR in March 2018, the US challenge to the appellate body mainly includes five aspects:

- without consultation with the parties and lack of transparency for more than 90 days.

- Allow outgoing judges to continue hearing pending cases.

- To Issue advisory opinions on matters not related to the resolution of a particular dispute.

- To review factual issues rather than legal issues only, including the re-examination of Member States' domestic laws.

- Use its decision as a precedent (rather than merely persuasive) for subsequent panels to follow (The Office of the US Trade Representative (USTR), 2018).

The 12 countries' Joint Plan submitted on November 26, 2018, responded to the above five concerns one by one. The EU-China-India Plan further put forward more radical recommendations. Caporal, J., \& Gerstel, D, 2018).

In particular, the response and recommendations of the Joint Plan are as follows:

- In terms of the 90 days, strengthen the consultation and transparency obligations of the Appellate Body. The joint proposal proposes to change the "however in no case shall the proceedings exceed 90 days" in Clause 17.5 of DSU to "however in no case shall the proceedings exceed 90 days unless the parties agree 
with other periods recommended by the appellate body. If Party disagrees with the extension of the time limit, and the appellate body considers that it is unable to decide within 90 days, the appellate body may, after consultation with the parties, recommend simplifying the relevant procedures or making special working arrangements to decide within 90 days; the parties shall cooperate in this regard.

- Concerning the issue of continuing trials of the outgoing judges, it is proposed to amend Article 17.2 of the DSU to clarify that the outgoing judges have the right to complete appeal cases that have already been heard in court.

- For rulings not related to the settlement of disputes, it is recommended that the existing disputes be resolved in existing clause 17.12 Article "The Appellate Body shall deal with every issue raised following paragraph 6 in the appeals process" and add the limitation "within limits necessary for the settlement of a dispute."

- Regarding the Appellate Body's decision as a precedent, the panel is required to comply with this issue when there are no "cogent reasons." It is suggested that the appellate body and WTO members should have full communication. The Joint Plan recommends the addition of DSU Article 17.15, which requires the Appellate Body to meet with WTO members once a year, at which any member can express their views on the decision of the Appellate Body that has been passed (however to respect the independence of the Appellate Body and impartiality) to provide additional "channels of communication" for both parties. Because of the urgency of the situation, the Joint Plan recommends that the WTO General Council adopted the above amendments "as soon as possible" (US NEWS, 2018)

If the "Joint Plan" is still based on persuading the United States and bridging differences, the "Europe, China and India Plan" submitted simultaneously as its supplement is even more tit-for-tat. The core proposals of the EUChina-India Plan are:

- increase the number of judges in the Appellate Body from 7 to 9;

- The term of office of a judge shall extend from 4 years (however renewable once) to 6 or 8 years (However, they cannot re-elect);

- The selection process of new judges will start automatically no later than a specified period (such as six months) before the end of the term of office of the outgoing judges. Among the three proposals, the third is to solve the imminent crisis and "breakthrough" the current selection impasse; the first two are more long-term oriented, aiming to enhance the appellate body's independence and members improve and enhance its work efficiency and capacity. Given the proposals mentioned above involving the amendments to Articles 17.1 and 17.2 of the DSU, the EU-China-India Program recommends that the General Council adopt these amendments together with the amendments contained in the Joint mentioned above (Program Marquet, C, 2018).

The Reform of the dispute settlement mechanism is by far China's most active and substantial participation in WTO reforms. it is also in line with the position paper that "WTO reform should prioritise the key issues endangering the survival of WTO as soon as possible to resolve the selection of members of the appellate body." From the proponents' perspective, especially the proponents of the joint plan EU, China, Canada, India, Norway, New Zealand, Switzerland, Australia, South Korea, Iceland, Singapore, Mexico-it can be said that the above reform plan has gathered quite a full consensus. The reasonably broad consensus is one of the few intersections between China and other significant WTO members, especially developed western economies in the current reform process. Although the United States' indifference to the plan mentioned above has worried its prospects, there is no doubt that China should continue to work with other members to promote it actively (US NEWS, 2018).

\section{Conclusion}

In 1995, after the inception of the World Trade Organization, it was expected that WTO would flourish more than GATT. However, after nearly two decades of its inception, WTO starts facing unprecedented crises as a whole and Dispute Settlement in particular. Reform has become a consensus; however, each member has different positions and views regarding the principles and specific content, so no consensus has yet arrived. However, due to the complicated interests involved, it is difficult to divide "factions" or "camps" among members. For example, in formulating new rules to constrain state-owned enterprises, remove investment barriers, and strengthen the policy review and supervision functions of the WTO, the advanced economies represented by the United States, Europe, and Japan are highly consistent, and their reform programs are focused at China. It is also quite obvious, however in terms of dispute settlement, the EU has joined forces with China, India, and other countries and is opposed to the United States, which is determined to go own way.

Contrary to US unilateral action, China always supports and promotes "together we grow" principle, strengthening 
its essential position and grasping the core concerns. In terms of negotiations mechanism, China claims that the Reform must follow consensus based on the decision-making mechanism; however, it does not predetermine the red area on the reform issue itself. In footings of substantive rules, China adheres to the traditional WTO position of "ownership neutrality," and opposes the reality of ownership discrimination in the name of "fair competition" and "competition neutrality." In terms of disciplinary constraints, adhere to developing countries' position and oppose the introduction of punitive measures no longer distinguished in terms of subsidy notification obligations. It is proposed in Dispute Settlement that deadlock in the selection of members of the AB should break and give essential elucidation and restriction to the authority of the appellate body.

\section{References}

Bartels, L. (2019). WTO Reform Proposals: Implications for Developing Countries. WTO Reform: Reshaping Global Trade Governance for 21st Century Challenges, 61. https://doi.org/10.14217/6741d22f-en

Bretton Woods project. (2019, May 07). What are the Bretton Woods Institutions. Retrieved from https://www.brettonwoodsproject.org/2019/01/art-320747/

Büge, M., Egeland, M., Kowalski, P., \& Sztajerowska, M. (2013). State-owned enterprises in the global economy: Reason for concern. CEPR's Policy Portal. Retrieved from https://voxeu.org/article/state-owned-enterprisesglobal-economy-reason-concern

Canada, G. (2018, October 25). Joint Communiqué of the Ottawa Ministerial on WTO Reform. Retrieved November 4, 2020, from https://www.canada.ca/en/global-affairs/news/2018/10/joint-communique-of-theottawa-ministerial-on-wto-reform.html

Caporal, J., \& Gerstel, D. (2018). WTO Reform: The Beginning of the End or the End of the Beginning? Centre for Strategic and International Studies. Saatavilla. Retrieved from http://www.globaltraderelations.net/images/Article.WTO_Reforms_CSIS_10.24.18_.pdf

China Economic Times. (2016). Learning from the Principle of Competitive Neutrality to Meet the Challenges of TPP SOE Clauses. China Economic Times 5th.

CNUCED. (2000). A positive agenda for developing countries: issues for future trade negotiations. UN. Retrieved from https://unctad.org/system/files/official-document/itcdtsb10_en.pdf

Deng, Y. (2020). The Role of the EU in Asian Security: Between Transatlantic Coordination and Strategic Autonomy. Asia Policy, 27(1), 105-126. https://doi.org/10.1353/asp.2020.0001

DSU-Article 17.1. (2018, September). Article 17.1 of the Understanding on Dispute Settlement Procedures and Rules. WTO. Retrieved from https://www.wto.org/english/res_e/publications_e/ai17_e/dsu_art17_oth.pdf According to Article 17.1 of the Understanding on Dispute Settlement Procedures and Rules, the WTO Appellate Body is composed of seven persons, and any one of the cases shall be tried by three of them and shall be rotated. However, due to US obstructions, as of September 2018, the Appellate Body has only three judges left, and two of them will leave office by the end of 2019. In other words, if the current stalemate in selection continues, the appellate body's "shutdown" is just around the corner.

Embassy of the PR China in the Republic of Rwanda. (2018, November 23). China's Position Paper on WTO Reform. Retrieved November 4, 2020, from http://rw.china-embassy.org/eng/xwdt/t1617375.htm In short, the three principles are: safeguard the core values of the multilateral trading system (non-discrimination and Release), protect the development interests of developing members, and follow a consensus decision-making mechanism; five points are: maintain the main channel of the multilateral trading system Position, prioritise key issues that threaten the survival of the WTO, address the issue of fairness of rules, respond to the needs of the times, and ensure the special Differential treatment and respect for members' respective development models.

EU and WTO. (2020, January 14). Joint Statement of the Trilateral Meeting of the Trade Ministers of Japan, the United States and the European Union. Retrieved from https://trade.ec.europa.eu/doclib/docs/2020/january/tradoc_158567.pdf

Lee, H. (2017). Applying Competition Policy to Optimise International Trade Rules. SSRN Electronic Journal. https://doi.org/10.2139/ssrn.2929110

Liangyu. (2018, November 02). Xi stresses unswerving support for development of private enterprises. Retrieved November 4, 2020, from http://www.xinhuanet.com/english/2018-11/02/c_137575231.htm

Marquet, C. (2018, December). The Appellate Body in Dire Straits: Taking a Step Back on Consent to Jurisdiction. 
In Society of International Economic Law (SIEL), Sixth Biennial Global Conference (2018).

Nakatomi, M. (2013). Plurilateral Agreements: A viable alternative to the WTO? The Future of the World Trading System: Asian Perspectives. Retrieved from https://www.wto.org/english/res_e/reser_e/wts_future2013_e/Nakatomi.pdf

Shaffer, G., \& Gao, H. (2018). China's Rise: How It Took on the US at the WTO. U. Ill. L. Rev., 115.

The Office of the US Trade Representative (USTR). (2018). Chapter I - The President's Trade Policy Agenda. In 2018 Trade Policy Agenda and 2017 Annual Report (pp. 1-32). Washington. Retrieved from https://ustr.gov/sites/default/files/files/Press/Reports/2018/AR/2018\%20Annual\%20Report\%20I.pdf

United Nations Economic and Social Commission for Asia and the Pacific. (2019). WTO Reform. Retrieved from https://www.unescap.org/sites/default/files/\%28China\%29\%20Statement $\% 20$ of $\% 20$ WTO\%20Reforme.pdf

US NEWS. (2018). US Not Swayed by WTO Reform Proposals. Retrieved November 4, 2020, from https://money.usnews.com/investing/news/articles/2018-12-12/us-not-swayed-by-wto-reform-proposals In an interview with reporters on the above plan, the United States Ambassador to the WTO, Shea, said that although "the United States complained to some extent," the solution was "just trying to modify certain rules to allow WTO judges to undermine "Regular behavior" and therefore "failure to address the issues raised by the United States."

World trade online. (2019). China criticises WTO transparency proposal advanced by US, others. Retrieved November 4, 2020, from https://insidetrade.com/trade/china-criticizes-wto-transparency-proposal-advancedus-others

WTO International Monetary Fund. (2019). Reinvigorating Trade and Inclusive Growth. Retrieved from https://www.wto.org/english/news_e/news18_e/igo_30sep18_e.pdf The unique characteristics of these new areas and their negotiation goals make this "unidirectional" possible. Because the negotiation goals are not The "concession" for exchange market access is to strengthen regulatory coordination, so the relevant negotiations and the rules they form may be inherently non-discriminatory: Domestic regulations involved make it difficult to "tailor-tailor" specific trade partners, making concerns about "discrimination" or "reciprocity" less relevant important.

WTO. (2017, February 22). WTO Agreement on Trade Facilitation. Retrieved November 4, 2020, from http://ffig.unece.org/contents/WTO_Agreement.htm The only exception is the Trade Facilitation Agreement adopted in December 2013, however it mainly involves simplifying customs clearance procedures and other procedures Sexual matters have limited significance and value in the creation of rules. Embassy of the PR China in the Republic of Rwanda.

WTO. (2018). WTO Modernization Introduction to Future EU Proposals. Retrieved from https://www.strtrade.com/media/publication/7804_WTO\%20modernisation\%20-\%20introduction $\% 20$ to\%2 Ofuture $\% 20 \mathrm{EU} \% 20$ proposals $\% 20-\% 20$ concept $\% 20$ note.pdf

WTO-General Council. (2018, December 13). Communication from The European Union, China, Canada, India, Norway, New Zealand, Switzerland, Australia, Republic Of Korea, Iceland, Singapore And Mexico To The General Council, $\quad W T / G C / W / 752 . \quad$ Retrieved from https://trade.ec.europa.eu/doclib/docs/2018/november/tradoc_157514.pdf

\section{Copyrights}

Copyright for this article is retained by the author(s), with first publication rights granted to the journal.

This is an open-access article distributed under the terms and conditions of the Creative Commons Attribution license (http://creativecommons.org/licenses/by/4.0/). 